\title{
A New Rapid Tissue Processing Technique for Small Oral Biopsies - A Comparative Study
}

\author{
Monica K. ${ }^{1}$, Gifrina Jayaraj², Herald J. Sherlin³, K.R. Don ${ }^{4}$, Archana Santhanam ${ }^{5}$ \\ 1, 2, 3,4,5 Department of Oral Pathology and Microbiology, Saveetha Dental College and Hospitals, Saveetha \\ Institute of Medical and Technical Sciences, Saveetha University, Chennai, Tamilnadu, India.
}

\section{ABSTRACT}

\section{BACKGROUND}

Histopathology is the examination of a biopsy or surgical specimen by a pathologist, after the specimen has been processed and histological sections have been placed onto glass slides. Histopathological diagnosis is an important aspect of medicine for further treatment. Tissue processing is the treatment of tissue through a series of reagents followed by final infiltration and embedding in a stable medium which when hardens provides the necessary support for microtomy. To reduce the turnover time, this newer rapid tissue processing technique was developed for routine histopathological diagnosis for small biopsies. The study aims to assess the efficacy of newer rapid tissue processing techniques compared with normal or routine tissue processing techniques.

\section{METHODS}

A comparative study with a total of 20 tissues were taken from formalin fixed tissues, which was cut into two halves, one set was processed with newer rapid tissue processing technique and another set by normal tissue processing followed by paraffin sectioning and staining with routine haematoxylin and eosin. Comparison between normal and rapid tissue processing for quality of staining was done.

\section{RESULTS}

Nuclear staining was good in $80 \%$ of the samples processed by routine processing and $60 \%$ of samples processed by rapid tissue processing, statistically it was not significant, $(\mathrm{U}=160.00, \mathrm{p}=0.173)$. Cytoplasmic staining was better in a rapid processing schedule with $60 \%$ compared to $55 \%$ in routine processing, the difference not statistically significant $(U=193, p=0.830)$.

\section{CONCLUSIONS}

Routine tissue processing is a gold standard procedure; factors affecting the practice are delay in diagnostic slide preparation and exposure to chemicals for longer time. This rapid tissue processing method showed good results. This processing can be used with small biopsy specimens on routine histopathological diagnosis.

\section{KEY WORDS}

Rapid, Routine, Tissue Processing, Small Biopsy
Corresponding Author:

Dr. Gifrina Jayaraj, Department of Oral Pathology, and Microbiology, Saveetha Dental College and Hospital, Chennai, Tamil Nadu, India. E-mail: gifrinaj@saveetha.com

DOI: $10.14260 /$ jemds $/ 2021 / 4$

How to Cite This Article: Monica K, Jayaraj G, Sherlin HJ, et al. A new rapid tissue processing technique for small oral biopsies - a comparative study. J Evolution Med Dent Sci 2021;10(01):19-22, DOI: $10.14260 /$ jemds/2021/4

Submission 03-09-2020,

Peer Review 05-11-2020,

Acceptance 12-11-2020,

Published 04-01-2021.

Copyright (c) 2021 Monica K. et al. This is an open access article distributed under Creative Commons Attribution License [Attribution 4.0 International (CC BY 4.0)] 


\section{BACKGROUND}

Biopsy is a common examination procedure essential for diagnosis of various diseases including cancers. ${ }^{1}$ There are various types of biopsies where the entire tissue affected is removed or a small part; a sample of tissue or fluid is removed with a needle and exfoliating cells are taken with the help of a brush. After the biopsy is performed, the sample of tissue that was removed from the patient is sent to the pathology laboratory. ${ }^{2}$ These tissues are processed with routine histopathological processes and treated with a series of reagents followed by final infiltration and embedding in a stable medium which when hard provides the necessary support for microtomy. ${ }^{3}$ This includes dehydration, clearing and infiltration. Dehydrating solutions are usually alcoholbased solutions which are required to remove water and fixatives such as formalin from the tissue specimen and replace it with alcohol.4 The tissue is then placed in xylene, a clearing agent which makes the tissue receptive to wax impregnation by the removal of alcohol. This is followed by infiltration - to permeate the tissue with a support medium and embedding - to orient the tissue specimen in a support medium and allowing it to solidify. This entire process takes 2 3 working days before a microscopic slide is ready for diagnosis. ${ }^{4}$ There are various means of processing methods they are, routine manual method; rapid manual method and the microwave method. Each of these methods is unique with their own advantages and disadvantages. ${ }^{5}$

Routine manual tissue processing has been the most commonly employed method for the past 100 years $^{5}$ that is more commonly used technique; reliability and inexpensive nature are the positive factors of this method. The disadvantages of this method are turnaround time of $21-24 \mathrm{~h}$ and exposure to noxious chemicals for longer time such as xylene and formalin.4-6 Even for small biopsy, delaying treatment for some critically ill patients and requiring additional shifts of technologists in the laboratory. ${ }^{7}$

Rapid manual tissue processing methods and recent microwave methods have shortened the processing times but do not reduce high cost and exposure to noxious chemicals. ${ }^{4}$ Rapid manual tissue processing is of a shorter duration than the above method, requiring $3-4 \mathrm{~h}$. It includes the same steps as in routine method, but for shorter durations. ${ }^{5}$ This technique reduces patients waiting time which is more important for psychological health of patients and helps in rapid histopathological diagnosis. Smaller biopsies can be processed in 2 - 5 hours using heat and vacuum. It starts with $10 \%$ formalin for tissue fixation (two changes) and proceeds for dehydration with graded concentration of alcohol starting with $70 \%, 95 \%$ (two changes) and $100 \%$ (two changes) followed by xylene for clearing (two changes) and paraffin for infiltration (two changes). A newer rapid tissue processing technique was developed with reduced processing time. The aim of this study is to check the efficacy of a newly proposed rapid tissue processing technique compared with normal or routine processing.

\section{METHODS}

\section{Sample Collection and Tissue Processing}

This is a comparative study which was conducted with approval from institutional ethical committee. The sample estimation was also done at convenience, a total of 30 paired formalin fixed tissues samples $(n=30)$ were retrieved from the resection specimens of the Department of Oral Pathology, Saveetha Dental College and Hospitals. The 30 tissue samples included i) mucosa, ii) adipose tissue, iii) muscle, iv) gland and v) random oral squamous cell carcinoma cases. Each tissue was cut into two halves measuring $1-3 \mathrm{~mm}$, one half was kept for routine tissue processing and the other was kept for rapid tissue processing. Our department has a customised processing schedule with alcohol and acetone ever since its inception that is employed for routine processing. The inhouse tissue processing protocol is dehydration done using isopropyl alcohol 30 minutes followed by acetone ( 2 changes) 30 minutes each followed by xylene ( 2 changes) 30 minutes for clearing and overnight impregnation. The rapid tissue processing schedule is isopropyl alcohol 10 minutes followed by acetone ( 2 changes) 10 minutes each followed by xylene ( 2 changes) 10 minutes each and impregnation (2 changes) 10 minutes each. The impregnated tissues were embedded and tissue sections of 3 micrometre were made using semiautomated soft tissue microtome by Leica (RM - 2245), Germany. Tissue sections were later stained with haematoxylin and eosin stain to assess tissue morphology. ${ }^{6}$ The usual time taken for conventional tissue processing is 24 hours.

\section{Evaluation of Slides}

The prepared microscopic slides examined by the pathologist blinded to the type of processing used. Evaluation is done based on nuclear staining, cytoplasmic staining and background staining of epithelium and connective tissue and artefacts. Scoring of nuclear and cytoplasmic staining was done. The histomorphological criteria for evaluation are as follows: 0 = Poor staining; 1 = Fair staining and morphology; 2 $=$ Good staining and morphology; $3=$ Excellent staining morphological characteristics. Background staining was observed for absence or presence using score; $0=$ absent; $1=$ Present. Artefacts were observed for absence or presence using scores: $0=$ Absent; 1 = Present.

\section{Statistical Analysis}

Scores were tabulated and statistical analysis performed using SPSS IBM version 20.0. Variables like nuclear staining, cytoplasmic staining, background staining and artefacts were compared with different tissue processing techniques with Mann Whitney U test. Among different tissue samples with Kruskal Wallis test done, $\mathrm{p}$ value $<0.05$ is considered statistically significant.

\section{RESULTS}

The results were obtained from histological examination. Analysis of nuclear staining showed different staining efficiency by different tissue samples. Nuclear staining was good in $80 \%$ of the samples processed by routine processing and $60 \%$ of samples processed by rapid tissue processing. Though the nuclear staining was better with a routine processing schedule. The difference was found to be statistically not significant, $(U=270.500, p=0.352)$. 
Cytoplasmic staining was better in a rapid processing schedule with $60 \%$ compared to $55 \%$ in routine processing. However, the difference was found to be statistically not significant $(\mathrm{U}=282.000, \mathrm{p}=0.507$ ). Background staining was $20 \%$ in rapid processing schedule compared to routine processing 35 $\%$. There was no statistically significant difference in the background staining between the two processing schedules (U $=287.500, \mathrm{p}=0.389$ ). Rapid processing schedule also had more artefacts compared to routine processing $(U=275.000$, $\mathrm{p}=0.399$ ). Comparisons of nuclear staining, cytoplasmic staining, background staining and artefacts between different tissue processing techniques, [Figure-1 and Figure-2], the mean rank for ordinal scales are measured, so no quantitative measures done, and Mann Whitney U test are summarised in Table-1.

\begin{tabular}{|c|c|c|c|c|}
\hline Parameters & $\begin{array}{l}\text { Processing } \\
\text { Methods }\end{array}$ & $\begin{array}{c}\text { Mean } \\
\text { Rank for } \\
\text { Ordinal }\end{array}$ & $\begin{array}{c}\text { Mann } \\
\text { Whitney U }\end{array}$ & P-Value \\
\hline \multirow[t]{2}{*}{ Nuclear Staining } & $\begin{array}{l}\text { Routine Tissue } \\
\text { Processing }\end{array}$ & 27.18 & \multirow[t]{2}{*}{270.500} & \multirow[t]{2}{*}{0.352} \\
\hline & Rapid Tissue Processing & 23.82 & & \\
\hline \multirow{2}{*}{$\begin{array}{l}\text { Cytoplasmic } \\
\text { Staining }\end{array}$} & $\begin{array}{l}\text { Routine Tissue } \\
\text { Processing }\end{array}$ & 24.28 & \multirow[t]{2}{*}{282.000} & \multirow[t]{2}{*}{0.507} \\
\hline & Rapid Tissue Processing & 26.72 & & \\
\hline \multirow{2}{*}{$\begin{array}{l}\text { Background } \\
\text { Staining }\end{array}$} & $\begin{array}{l}\text { Routine Tissue } \\
\text { Processing }\end{array}$ & 24.50 & \multirow{2}{*}{287.500} & \multirow{2}{*}{0.389} \\
\hline & Rapid Tissue Processing & 26.50 & & \\
\hline \multirow[t]{2}{*}{ Artefacts } & $\begin{array}{l}\text { Routine Tissue } \\
\text { Processing }\end{array}$ & 24.00 & \multirow[t]{2}{*}{275.000} & \multirow[t]{2}{*}{0.399} \\
\hline & Rapid Tissue Processing & 27.00 & & \\
\hline \multicolumn{5}{|c|}{$\begin{array}{l}\text { Table 1. Overall Staining Characteristics of the Tissue Samples } \\
\text { between the } 2 \text { Schedules. Mann Whitney Test }\end{array}$} \\
\hline
\end{tabular}

As far as the individual tissues were concerned, tissue processed by routine processing cycle had better nuclear staining compared to rapid processing. Random oral squamous cell carcinoma cases showed excellent and mucosa had good nuclear staining in both routine and rapid processing schedule. There was no significant difference in the nuclear staining of individual tissues between the processing schedules $(p>0.05)$. Cytoplasmic staining of glandular tissue was better with a rapid processing schedule compared to the routine processing. Random oral squamous cell carcinoma cases showed excellent cytoplasmic staining comparatively in routine and rapid tissue processing techniques. However, there was no significant difference in the cytoplasmic staining of individual tissues between the processing schedules. Nuclear and cytoplasmic staining is summarised in Table-2.

\begin{tabular}{|c|c|c|c|c|c|c|c|}
\hline \multirow{3}{*}{\begin{tabular}{|c} 
Tissue Samples \\
$\begin{array}{c}\text { Histomorphological } \\
\text { criteria }\end{array}$
\end{tabular}} & \multicolumn{6}{|c|}{ Nuclear Staining } & \multirow{3}{*}{$\begin{array}{c}\text { Kruskal } \\
\text { Wallis } \\
\text { P value }\end{array}$} \\
\hline & \multicolumn{3}{|c|}{$\begin{array}{l}\text { Routine Tissue } \\
\text { Processing }\end{array}$} & \multicolumn{3}{|c|}{$\begin{array}{c}\text { Rapid Tissue } \\
\text { Processing }\end{array}$} & \\
\hline & Fair & Good & Excellent & Fair & Good & Excellent & \\
\hline Skin & 40 & 60 & 0 & 80 & 20 & & 0.221 \\
\hline Gland & 40 & 60 & 0 & 60 & 40 & & 0.549 \\
\hline Muscle & 0 & 100 & 0 & 20 & 80 & & 0.317 \\
\hline Mucosa & 0 & 100 & 0 & 0 & 100 & & 1.00 \\
\hline \multicolumn{8}{|c|}{ Cytoplasmic staining } \\
\hline Skin & 30 & 60 & 10 & 40 & 20 & 40 & 1.000 \\
\hline Gland & 40 & 20 & 40 & 0 & 80 & 20 & 0.734 \\
\hline Muscle & 0 & 40 & 60 & 0 & 40 & 60 & 1.000 \\
\hline Mucosa & 0 & 100 & 0 & 0 & 100 & 0 & 1.000 \\
\hline
\end{tabular}

In the routine processing schedule, all the samples of glands $(100 \%)$, muscle $(100 \%)$ and oral squamous cell carcinoma (100\%) did not have background staining whereas $20 \%$ of the gland and mucosal samples had background staining with rapid processing. There was no significant difference in the background staining of individual tissues between the processing schedules.

$60 \%$ of skin and mucosa samples show artefacts in both the processing techniques. No significant difference seen in artefacts among different tissue samples. Comparison of nuclear staining, cytoplasmic staining, background staining and artefacts among different tissue samples using KruskalWallis test are summarised in Table-2 and Table-3.

\begin{tabular}{|c|c|c|c|c|c|}
\hline \multicolumn{6}{|c|}{ Background Staining } \\
\hline \multirow[t]{2}{*}{$\begin{array}{l}\text { Tissue } \\
\text { Samples }\end{array}$} & \multicolumn{2}{|c|}{$\begin{array}{l}\text { Routine Tissue } \\
\text { Processing }\end{array}$} & \multicolumn{2}{|c|}{$\begin{array}{l}\text { Rapid Tissue } \\
\text { Processing }\end{array}$} & \multirow{2}{*}{$\begin{array}{c}\text { Kruskal } \\
\text { Wallis } \\
\text { P Value }\end{array}$} \\
\hline & Absent & Present & Absent & Present & \\
\hline Skin & 60 & 40 & 60 & 40 & 1.00 \\
\hline Gland & 100 & 0 & 80 & 20 & 0.317 \\
\hline Muscle & 100 & 0 & 100 & 0 & 1.00 \\
\hline Mucosa & 0 & 100 & 80 & 20 & 0.317 \\
\hline \multicolumn{6}{|c|}{ Artefacts } \\
\hline Skin & 40 & 60 & 40 & 60 & 1.000 \\
\hline Gland & 80 & 20 & 60 & 40 & 0.513 \\
\hline Muscle & 40 & 60 & 20 & 80 & 0.513 \\
\hline Mucosa & 40 & 60 & 40 & 60 & 1.000 \\
\hline $\begin{array}{r}\text { Table } 3 . \\
\text { Tissue } \\
\text { Com }\end{array}$ & ckgroun & $\begin{array}{l}\text { taining a } \\
\text { Two Proc }\end{array}$ & $\begin{array}{l}\text { Artefact } \\
\text { sing Sche }\end{array}$ & $\begin{array}{l}\text { haracteris } \\
05=\text { Signi } \\
\text { les }\end{array}$ & $\begin{array}{l}\text { cs of the } \\
\text { Group } \\
\text { cant) }\end{array}$ \\
\hline
\end{tabular}
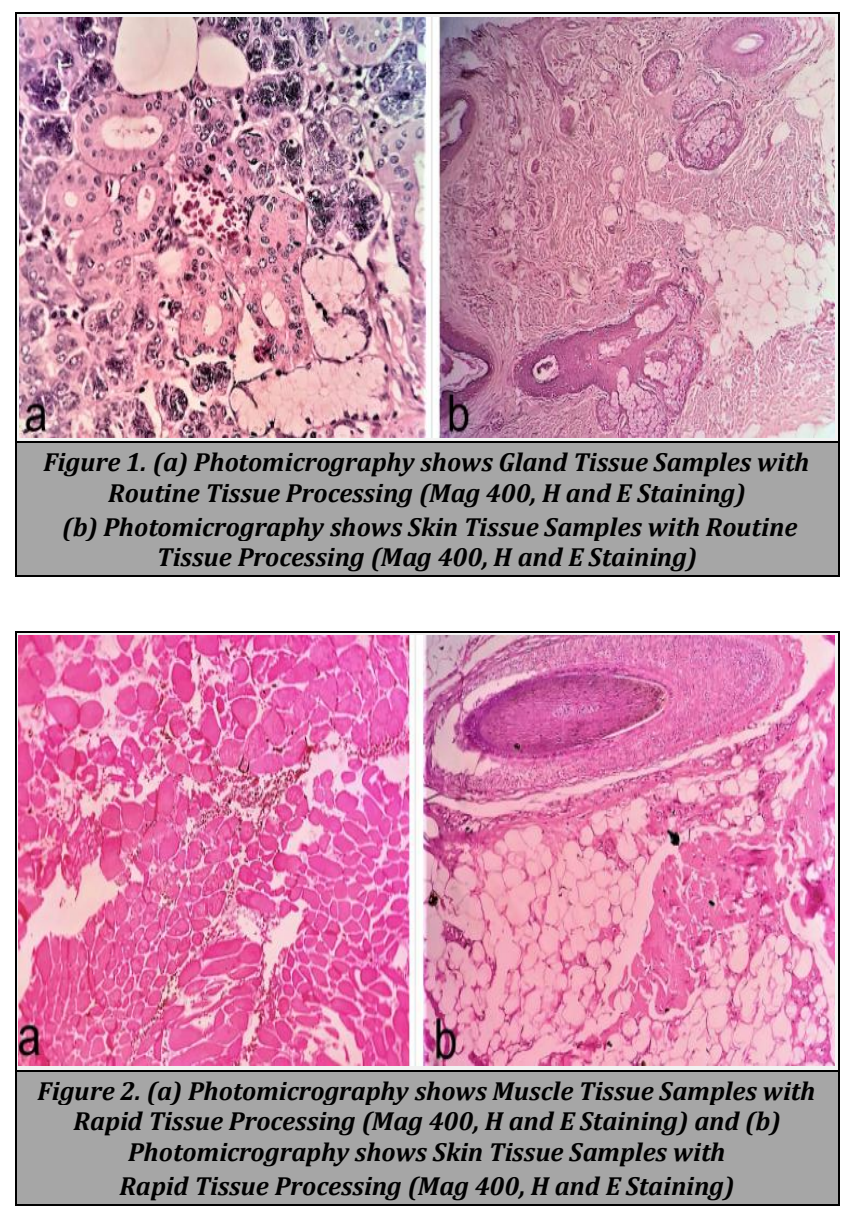

\section{DISCUSSION}

Diagnostic pathology is largely dependent on formalin-fixed paraffin-embedded tissue sections. Even with various advances in histopathological diagnosis, still routine tissue 
processing is the gold standard method followed most commonly. The increased turnaround time, even for small biopsies, patient waiting time increased was leading to higher stress levels. 4,8 So this newer rapid tissue processing technique is available with reduced turnaround time (TAT). This rapid tissue processing is shorter with 1.30 minutes to 2 hours for pre fixed formalin tissue. Can be used for small biopsy samples, when rapid diagnosis is required. The good advantage is very less time involved compared to routine tissue processing methods. ${ }^{6}$

The important aspect of tissue processing is diffusion of reagents into the substance of the tissue to be processed. ${ }^{9}$ These two different processing methods followed in current study did not show any significant variations in quality of staining with haematoxylin and eosin.

In the current study, the nuclear and cytoplasmic staining in epithelial and connective tissue were of acceptable diagnostic quality with the employed rapid tissue processing schedule. Random oral squamous cell carcinoma cases showed comparatively excellent results in rapid and routine tissue processing, hence can be used for smaller biopsy cases with better quality. Mucosal sample specimens showed good nuclear and cytoplasmic staining followed by muscle specimens. This may be due to thinner, less dense mucosal samples which are not affected by lesser exposure time. Studies show mucosa in the oral cavity differs in thickness, highest in buccal mucosa $(-659.79 \mu \mathrm{m})$ and thinnest in floor of the mouth $(-100.07 \mu \mathrm{m}) .10,6$ Knowledge on these structural variations is needed for processing denser tissues that need more reagents and exposure time followed by fresh solutions for further processing. ${ }^{11}$ Our present study did not show any difference between the two processing schedules. These findings are similar to Karnam et al. ${ }^{4}$ and Boon et al., ${ }^{12}$ Jali et al. also showed no significant differences in the microscopic quality of the stained sections with rapid tissue processing. 8

Artefacts are reported to be an unrelated feature which compromises the diagnosis, may alter normal morphologic and cytological features or even lead to complete uselessness of the tissue. ${ }^{11}$ Current study showed comparatively higher artefacts in tissue samples with rapid tissue processing, although, there was no statistically significant difference between the two groups. These findings were in concordance with Karnam et al. ${ }^{4}$ Artefacts may be due to insufficient dehydration or clearing of the tissue samples. Other factors like pre-fixation artefacts or fixation artefacts are also reported. ${ }^{9}$ Artefacts can be reduced by standardization of timing for good exposure of tissues. ${ }^{13}$

The overall qualities of both the tissue processing techniques among different parameters were closely comparable and had sufficient diagnostic quality. Even with lack of any significant differences in the performance of the rapid tissue processing, the schedule suggested in this study can be used for rapid processing for small biopsies without loss of quality of sample for diagnosis. This study also shows reduced cost, reduced time taken and reduced exposure time to noxious material during the process. In future, this study can incorporate standardization of timings in each solution. This rapid processing technique can be tried with decalcified hard tissue samples with different tissue samples with increased specimen thickness.

\section{CONCLUSIONS}

Routine tissue processing is a gold standard procedure; however, it has a major disadvantage of being time consuming. In order to arrive at a rapid diagnosis for urgent biopsies we tried a new rapid tissue processing method. Study showed good results, and this processing can be used on emergency small biopsy specimens on routine histopathological diagnosis thereby reducing the turnaround time.

Data sharing statement provided by the authors is available with the full text of this article at jemds.com.

Financial or other competing interests: None.

Disclosure forms provided by the authors are available with the full text of this article at jemds.com.

\section{REFERENCES}

[1] Mota-Ramírez A, Silvestre FJ, Simó JM. Oral biopsy in dental practice. Med Oral Patol Oral Cir Bucal 2007;12(7):E504-10

[2] Moore GE. The importance of biopsy procedures. The Journal of the American Medical Association 1968;205(13):917-20.

[3] Culling CF. Handbook of histopathological and histochemical techniques: including museum techniques. Butterworth-Heinemann 2013: p. 726.

[4] Karnam S, Girish HC, Murgod S, et al. Rapid tissue processing technique: a novel method using methyl salicylate. J Oral Maxillofac Pathol 2018;22(3):443.

[5] Sundharam S, Panja P, Sriram G, et al. Comparison of three different methods of tissue processing. J Oral Maxillofac Pathol 2007;11(1):15-7.

[6] Spencer LT, Bancroft JD. Tissue processing. In: Gamble M, Bancroft JD, eds. Theory and practice of histological techniques. Churchill Livingstone Elsevier Limited 2008:83-92.

[7] Rohr LR, Layfield LJ, Wallin D, et al. A comparison of routine and rapid microwave tissue processing in a surgical pathology laboratory. Am J Clin Pathol 2001;115(5):703-8.

[8] Jali PK, Donoghue M, Gadiwan M. A rapid manual processing technique for resource- limited small laboratories. J Oral Maxillofac Pathol 2015;19(3):306-14.

[9] Ekundina VO, Eze G. Common artifacts and remedies in histopathology (a review). African Journal of Cellular Pathology 2015;4:6-12.

[10] Stasio DD, Lauritano D, Iquebal H, et al. Measurement of oral epithelial thickness by optical coherence tomography. Diagnostics (Basel) 2019;9(3):90.

[11] Margarone JE, Natiella JR, Vaughan CD. Artifacts in oral biopsy specimens. J Oral Maxillofac Surg 1985;43(3):16372.

[12] Boon ME, Kok LP, Ouwerkerk-Noordam E. Microwavestimulated diffusion for fast processing of tissue: reduced dehydrating, clearing and impregnating times. Histopathology 1986;10(3):30-9.

[13]Ficarra G, McClintock B, Hansen LS. Artefacts created during oral biopsy procedures. J CranioMaxillofac Surg 1987;15(1):34-7. 